\title{
Searching for Silence
}

\author{
Izabela Zawadzka \\ Jagiellonian University \\ Theatre and Drama Department, Gołębia 14-16, 30-007 Krakow, Poland \\ Izabela.zawadzka@doctoral.uj.edu.pl
}

\begin{abstract}
One in five citizens of European cities are exposed to harmful sound levels. Noise pollution is nowadays one of the most widespread and at the same time most persistently ignored hazards in the civilized world. In a visually oriented society soundscapes change rapidly and protection of them is an issue that attracts marginal attention. The paper describes how Witold Lutosławski and Raymond Murray Schafer fought for silence and clarity of sound. The description of the World Soundscape Project demonstrates how everyday sounds can be rethought and creative ways of activating the public to take care of the soundscapes around them developed. The paper focuses on a series of workshops held in Krakow, Poland. Four meetings with different groups of citizens (high-school students, university students, senior citizens, and people with visual impairments) provided the material for an analysis of how people's reactions change when they take a walk focusing on the soundscape. They also provided an opportunity to explore the differences in the perception of soundwalks by fully sighted citizens and those with visual impairments.
\end{abstract}

Sound studies. Silence. Soundscape. Acoustic ecology. Artistic education.

\section{INTRODUCTION}

When was the last time you listened? Deeply immersed yourself in the sounds of everyday life? Willingly sought out the sources of the sounds around you?

Our brain is constantly receiving all kinds of sounds. The auditory cortex responds to them and produces impulses on the same frequency as that of the sound being heard. During the process of habituation our brain learns which sounds could signal danger and which are harmless (Levitin, 2007). Thereafter we soon learn to ignore those which are insignificant. This may be observed in everyday situations. For example, after sitting in the kitchen for a while, we stop hearing the buzzing of the refrigerator; we get used to it. The same happens with background noise on the street. In the process of grouping the sounds, our brain catalogues all varieties of humming, buzzing, and droning as street sounds.

\section{THE RIGHT TO SILENCE}

Raymond Murray Schafer in his The $N$ ew Soundscape (Schafer, 1969) wrote:

Anything in our world that moves vibrates air.

If it moves in such a way that it oscillates at more than about 16 times a second this movement is heard as sound.

The world, then, is full of sounds. Listen.
Openly attentive of whatever is vibrating, listen.

Sit quietly for a moment and receive.

The sounds of the city attack our ears from every side, and we are vulnerable to them. Witold Lutosławski, one of the most influential Polish composers of the $20^{\text {th }}$ century, was also one of the first Polish activists who fought against sound pollution. He claimed that we are slaves of the world around us. We cannot close our ears and stop hearing. All we can do is not listen, but that means that we blunt our sensitivity to music and sounds. For Lutosławski the invention of the transistor radio was the beginning of the death of music. Once these small radio receivers became popular, people could play music everywhere. Lutosławski held that they were real threats to music, and that people who expose others to music without their consent are its enemies. As an example he cited music played in hotel elevators, bars, and taxis. He believed that everyone should have a choice as to what and when to listen to. Lutosławski was one of the members of the General Assembly of the UNESCO International Music Council which in October 1969 passed a resolution about the human right to silence (Skowron, 2007).

The World Health Organization has issued warnings about the damage noise can do to citizens, especially in large cities. In Europe, almost one in five people are exposed to harmful levels of sound. Noise is everywhere - at schools, in workplaces, at home - and it is a real threat to human health, as a 
cause of cardiovascular and psychophysiological problems (World Health Organization, 2018).

People are not used to listening. We live in a visually oriented society, and are trained to watch carefully. In Poland a typical art education is based on the visual arts (painting and drawing), with music still considered a specialist field. ${ }^{1}$ The language used to describe classical music and compositions is somewhat arcane and canonical, and students are taught not to speak about sounds in any other way. In schools the only sounds that 'matter' are composed ones, and consequently students do not learn to be attentive to the audiosphere they live in and build.

It was precisely activation of a sensitivity to the audiosphere that was the goal of Raymond Murray Schafer. In the late 1960s he established a research and education group called the World Soundscape Project, whose main goal was to record and preserve rapidly changing soundscapes in order to draw the attention of city dwellers to the sources of the sounds around them. After its first experiments in Vancouver the group visited Sweden, Germany, Italy, France, and the UK, comparing the sounds of different regions. ${ }^{2}$ The notes and observations of the World Soundscape Project were published in two separate books: Five Village Soundscapes (1977) and European Sound Diary (1977). Beside the texts, photographs, and drawings, the books also contain sound walks - maps with descriptions of routes for walks, including sights and sounds to pay attention to on the way.

This rethinking of soundscapes, and blending of sound- and landscapes into single, interdisciplinary wholes, was the inspiration for the Tetro Collective to create city listening workshops. The Tetro Collective comprises three PhD performative arts and theatre students from the Jagiellonian University: Jakub Papuczys, Katarzyna Waligóra, and Izabela Zawadzka. The workshops took place at the Museum of Municipal Engineering in Krakow ${ }^{3}$ as part of the Sound of Changes initiative launched by five European museums interested in the sounds of everyday life in cities.

\section{LEARN TO LISTEN}

The goal of the project undertaken by the Tetro Collective was to raise the awareness of citizens of Krakow of the noise pollution in our city. The group led four workshops, each one aimed at a different group: high-school students, university students of culture studies, seniors living in the Kazimierz district, where the Museum of Municipal Engineering is located, and people with visual impairments.

Each of the workshops included a walk through the neighbourhood. This was a silent walk, during which the participants were asked to listen to the city, be aware of the sounds surrounding them, and think about the emotions evoked by each of them. Before the walks the groups talked about the World Soundscape Project and its research. This also provided the inspiration for the participants to create soundmaps.

Of the many remarks and conclusions yielded by the workshops, three are most relevant for further consideration.

First, searching for silence in the city is frustrating. All of the participants were annoyed by the intensity of the sounds surrounding them on the soundwalk, even though they had frequented the same places before the workshops. Focusing on the audiosphere made all the loud sounds seem even louder. One of the senior citizens said that a car going past had irritated her so badly that she couldn't think about any of the other sounds - and she lived near the museum and frequently walked along the same street, so that the noise of the cars cannot have been new to her.

In the Polish edition of Vogue Magazine one of the non-fiction contributors, Filip Springer (an awardwinning writer specializing in features about architecture), wrote a series of articles about silence and his search for it. In an interview with Marcin Dymiter, a Polish composer and sound experimenter, Dymiter told him "I don't think you are looking for silence. There is no such thing. You are looking for hi-fi" (Springer, 2019). Dymiter understands hi-fi in the same way as Schafer did: as a soundscape in which every sound can be heard clearly, without distractions. Hi-fi soundscapes are distinguished by the low ambient noise level. In the city we can usually find hi-fi in religious spaces. In the Kazimierz district these included the interior of a church and an old Jewish cemetery. These were oases of quiet amid the noise of their urban surroundings. Their unusual soundscapes prompted people to act quietly, step softly, and whisper instead of talking. Even though this was not technical silence, the clarity of individual sounds created a calm and pleasant audiosphere.

The second observation was that the participants (especially the students) had considerable problems talking about the sounds. Their use of vocabulary for describing particular sounds was sloppy. In their descriptions of the landscape they used a wide variety of specific terms. At the same time in the matter of sounds they seemed oblivious to the notion of differentiating between, for instance, murmuring and whirring. It was also interesting to see how the same Polish words for sounds can be interpreted differently. For example: szum is used to describe both natural sounds (as made by leaves on trees rustling) and monotonous mechanical sounds (such as the humming sound of an engine running smoothly) - the same name for both a pleasant and 
an irritating sound, for something artificial and something natural.

In the end it was the work with the group of people with visual impairments that yielded the most surprising findings. This workshop was led by a qualified pedagogue, Barbara Pasterak, who creates workshops and support materials for people with sight issues, and works to make the visual arts more accessible for them. The city as heard by the participants of this workshop was an entirely different space. What was most surprising was the contrast between the perceptions of what constituted threatening and non-threatening noises in the public space by the participants with visual impairments on the one hand and the sighted leaders of the workshop on the other. The route of the soundwalk taken during the meeting led past a construction site. This was quite a loud experience with a lot of untypical sounds. Nonetheless, the participants did not consider it something dangerous. They heard it and recognized it as some kind of construction work, which to them meant that there must be some form of protection system (e.g. barriers) to help them pass safely by. Electric cars, fast bicycles, people running - these are to them the sounds which most signal danger because they indicate something approaching at high speed, with little warning, and are very quiet and thus hard to pick out. Other difficulties for them are crowded streets (people generate a mass of sounds, making it impossible to hear others in the surroundings) and pedestrian crossings. Even though these latter usually generate some kind of sound signals (which are so irritating for people living nearby), there is no unified system of coordination between the signal type and the colour of the light. Some buzz or bleep only when there is a green light for pedestrians, some are emitted more slowly as a warning when the traffic lights change to amber, some crossings make no sounds at all, and some are silent when the pedestrian lights are red. Without a single, clear, well thought-out system, such aids for people with visual impairments are pointless.

Working with the people with visual impairments was an exciting experience. Although this was a very small group, we were able to make some observations that corroborated our previous experiences in work with people with disabilities. ${ }^{4}$ The workshops proved that there is a spectrum of visual disability and it is hard to give a blanket summary of the experiences of members of this group in respect of soundscapes. During the workshops we worked with one man who had not seen since birth and with another who functions in everyday life without any special aids, because he is partially sighted. Some of the participants were extremely sensitive to the sounds around them, while others treated the soundscapes in broadly the same way as people without disabilities - they did not notice quieter background sounds, but concentrated on certain types of louder ones (e.g. footsteps, passing cars, people talking).

One of the most interesting parts of each workshop was inviting the participants to create their own soundmaps. The aim of this exercise was to engage another sense in thinking about the soundscape experienced during the silent walk. This transition captured the participants' imagination. The groups of high-school students, senior citizens, and university students (though shyly at first) playfully rewrote the sounds of the city into collages, sketches, and colourful maps. They used varying techniques and took a range of approaches to the soundscapes, all of which were closely connected with the diversity of the hearing and listening process. In the group of people with visual impairments we invited the participants to use a variety of different materials to convey how they sensed the sounds we were talking about. Was the rain silky like fabric? Or puffy like cotton wool? The participants had difficulties in participating in this exercise. It transpired that the visually impaired people in this group could not rethink the sounds as something abstract, tactile, or sensual. Sounds for them are signals, symbols of something material, references to reality.

The workshops showed how little people are aware of the soundscapes. We are habituated to loud urban sounds, but when we start to listen to them carefully they they seem almost to explode in our ears. Our work with these diverse groups of participants showed that silent walks and creating visual equivalents to soundscapes make people more conscious about the audiosphere in which they function and to which they themselves also contribute. For the Tetro Collective it was the first step in the soundwalk project. The workshops showed that people with visual impairments can be extremely interesting guides through the soundscape of the city. Their contribution to understanding and experiencing the sounds of the city is extremely precious. The work with fully sighted people proved that isolating background noises makes them more attentive to the soundscape, which, I believe, is the first step to fighting noise pollution in the city.

\section{References}

Levitin, D.J. (2007) This Is Your Brain on Music: The Science of a $\mathrm{H}$ uman O bsession. New York: Plume/Penguin.

Skowron, Z. (2007) Lutosławski on Music. Lanham: Scarecrow Press.

Schafer, R.M. (1969) The New Soundscape. Scarborough, Ontario: Berandol Music Limited. 
Springer, F. (2019) Springer szuka ciszy. Pejzaż, Vogue from https://www.vogue.pl/a/springerszuka-ciszy-pejzaz (4 August 2019).

World Health Organization (2018), Environmental Noise Guidelines for the European Region.

1. In public primary schools in Poland music is only taught in four years (Years 4-7, children aged 11-14), with a provision of one hour per week mandatory under Polish law. At secondary level, only first-year pupils have any form of art education, again only one lesson a week. The headteacher has to choose between providing philosophy, music, or visual arts. Only specialist music schools with the specific mandate of educating professional musicians provides a full musical education (including history of music and the rudiments of contemporary music). See also: Dz.U. 2017 poz. 703, Rozporządzenie Ministra Edukacji Narodowej z dnia 28 marca 2017 r. w sprawie ramowych planów nauczania dla publicznych szkół.

2. The World Soundscape Project, see also: https://www.sfu.ca/ truax/wsp.html (4 August 2019)

3. The Museum of Municipal Engineering in Krakow, see also: https://www.mim.krakow.pl/ (4 August 2019).

4. Barbara Pasterak and Izabela Zawadzka work at The Centre for the Documentation of the Art of Tadeusz Kantor CRICOTEKA in Krakow, where they organize inclusive events (performances, workshops, talks) open to people both without and with disabilities. 